\title{
Hydraulic Conductivity of Near-Surface Alluvium in the Vicinity of Cattlemans Detention Basin, South Lake Tahoe, California
}

Open-File Report 2004-1201

Prepared in cooperation with the EL DORADO COUNTY DEPARTMENT OF TRANSPORTATION, TAHOE ENGINEERING UNIT and CALIFORNIA TAHOE CONSERVANCY

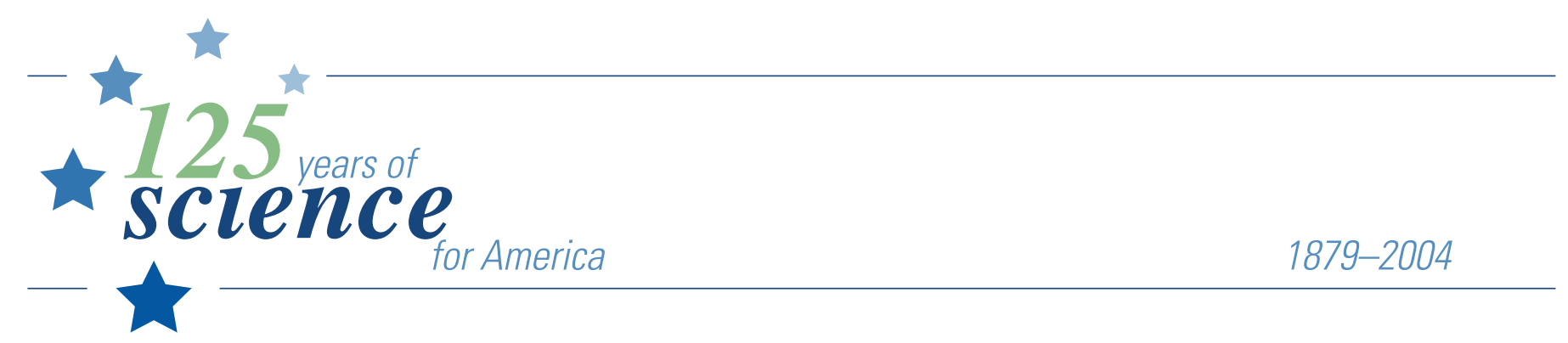

U.S. Department of the Interior 
(Back of Cover) 


\title{
Hydraulic Conductivity of Near-Surface Alluvium in the Vicinity of Cattlemans Detention Basin, South Lake Tahoe, California
}

\author{
By Jena M. Green, Katherine K. Henkelman, and Rachel M. Caskey
}

Open-File Report 2004-1201

Prepared in cooperation with the EL DORADO COUNTY DEPARTMENT OF TRANSPORTATION, TAHOE ENGINEERING UNIT and

CALIFORNIA TAHOE CONSERVANCY

Carson City, Nevada 


\title{
U.S. DEPARTMENT OF THE INTERIOR GALE A. NORTON, Secretary
}

\author{
U.S. GEOLOGICAL SURVEY \\ CHARLES G. GROAT, Director
}

Any use of trade, product, or firm names in this publication is for descriptive purposes only and does not imply endorsement by the U.S. Government

For additional information contact:

\section{District Chief}

U.S. Geological Survey 333 West Nye Lane, Room 203 Carson City, NV 89706-0866

email: GS-W-NVpublic-info @ usgs.gov http://nevada.usgs.gov
Copies of this report can be purchased from:

U.S. Geological Survey Information Services Building 810 Box 25286, Federal Center Denver, CO 80225-0286 


\section{CONTENTS}

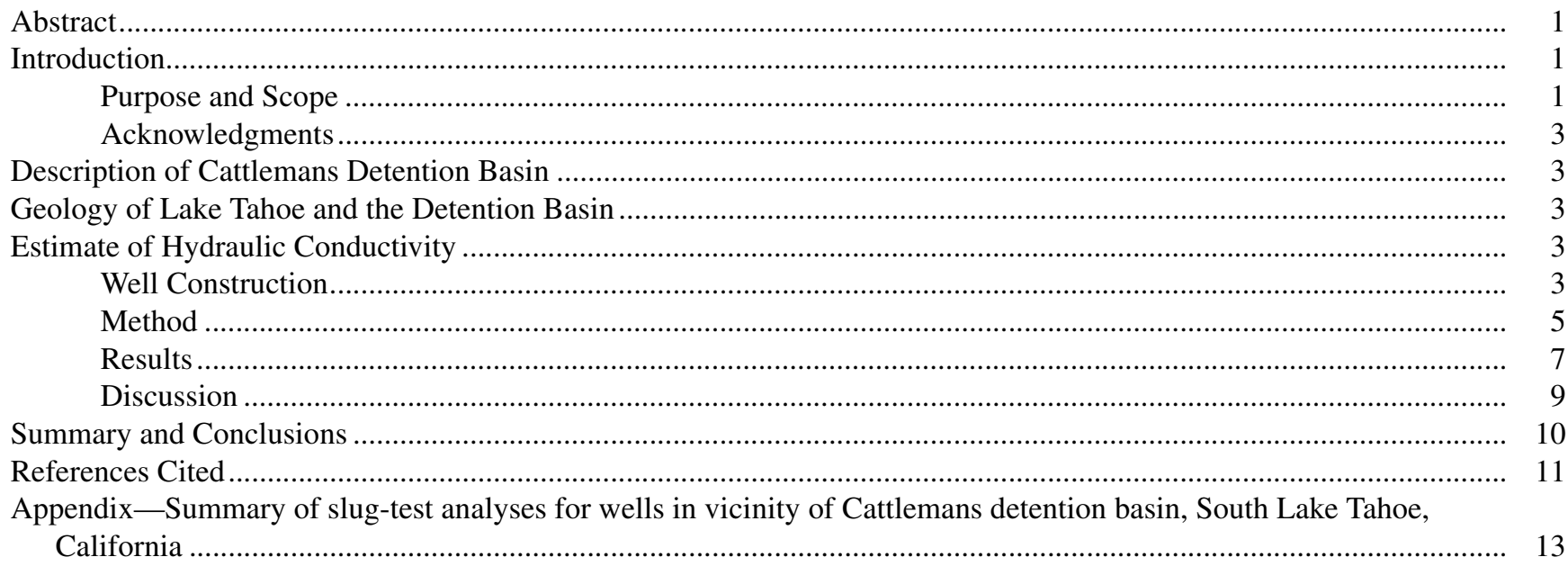

\section{FIGURES}

1. Map showing location of Cattlemans detention basin with respect to Lake Tahoe and California, USA ............. 2

2. Map showing location of Cattlemans detention basin in relation to Cold Creek, Pioneer Trail, and Cattlemans Court, South Lake Tahoe, California .....

3. Vertical cross-section showing distribution of alluvial deposits and fill materials between well 3 and well 14 at Cattlemans detention basin, South Lake Tahoe, California

4. Schematic showing construction of wells near Cattlemans detention basin, South Lake Tahoe, California......... 7
5. Map showing the distribution of hydraulic conductivity near Cattlemans detention basin, South Lake Tahoe, California..

6. Bar graph showing the range of hydraulic conductivity in all tested wells near Cattlemans detention basin, South Lake Tahoe, California

\section{TABLES}

1. Well name, land-surface elevation, and construction data for wells in vicinity of Cattlemans detention basin, South Lake Tahoe, California ......

2. Results of slug tests in wells near Cattlemans detention basin, South Lake Tahoe, California... 
CONVERSION FACTORS AND VERTICAL DATUM

\begin{tabular}{rll}
\hline Multiply & By & To obtain \\
acre & 0.00405 & square kilometer $\left(\mathrm{km}^{2}\right)$ \\
cubic foot $\left(\mathrm{ft}^{3}\right)$ & 0.02832 & cubic $\left.\mathrm{meter}^{2} \mathrm{~m}^{3}\right)$ \\
foot $(\mathrm{ft})$ & 0.3048 & meter $(\mathrm{m})$ \\
foot per day (ft/d) & 0.3048 & meter per day $(\mathrm{m} / \mathrm{d})$ \\
gallon (gal) & 3.785 & liter $(\mathrm{L})$ \\
inch (in.) & 25.4 & millimeter \\
mile (mi) & 1.609 & kilometer \\
square mile $\left(\mathrm{mi}^{2}\right)$ & 2.590 & square kilometer
\end{tabular}

Temperature: Degrees Celsius $\left({ }^{\circ} \mathrm{C}\right)$ can be converted to degrees Fahrenheit $\left({ }^{\circ} \mathrm{F}\right)$ by using the formula ${ }^{\circ} \mathrm{F}=\left[1.8\left({ }^{\circ} \mathrm{C}\right)\right]+32$. Degrees Fahrenheit can be converted to degrees Celsius by using the formula ${ }^{\circ} \mathrm{C}=0.556\left({ }^{\circ} \mathrm{F}-32\right)$.

Sea level: In this report, "sea level” refers to the National Geodetic Vertical Datum of 1929 (NGVD of 1929, formerly called "Sea-Level Datum of 1929"), which is derived from a general adjustment of the first-order leveling networks of the United States and Canada. 


\title{
Hydraulic Conductivity of Near-Surface Alluvium in the Vicinity of Cattlemans Detention Basin, South Lake Tahoe, California
}

\author{
By Jena M. Green, Katherine K. Henkelman, and Rachel M. Caskey
}

\section{Abstract}

Cattlemans detention basin, South Lake Tahoe, California is designed to capture and reduce urban runoff and pollutants originating from developed areas before entering Cold Creek, which is tributary to Trout Creek and to Lake Tahoe. The effectiveness of the basin in reducing sediment and nutrient loads currently is being assessed with a five-year study. Hydraulic conductivity of the alluvium near the detention basin is needed to estimate ground-water flow and subsurface nutrient transport. Hydraulic conductivity was estimated using slug tests in 27 monitoring wells that surround the detention basin. For each test, water was poured rapidly into a well, changes in water-level were monitored, and the observed changes were analyzed using the Bouwer and Rice method. Each well was tested one to four times. A total of 24 wells were tested more than once. Of the 24 wells, the differences among the tests were within 10 percent of the average. Estimated hydraulic conductivities of basin alluvium range from 0.5 to 70 feet per day with an average of 17.8 feet per day. This range is consistent with the sandy alluvial deposits observed in the area of Cattlemans detention basin.

\section{Introduction}

Detention basins have been constructed in South Lake Tahoe, California to reduce the effects of urban runoff (fig. 1). Urban runoff is a concern in the Lake Tahoe basin because nutrients associated with urban runoff can decrease the clarity of Lake Tahoe. Detention basins should reduce nutrient loads to Lake Tahoe by settling suspended solids and filtering runoff through alluvium. The amount of nutrient reduction from detention basins in South Lake Tahoe is unknown.

Cattlemans detention basin project began in November 2000 and is a cooperative study between the U.S. Geological Survey, the El Dorado County Department of Transportation, Tahoe Engineering Unit, and the California Tahoe Conservancy. The purpose of this five-year study is to determine whether the capture of urban runoff into Cattlemans detention basin reduces nutrients and sediments entering nearby Cold Creek, which is tributary to Lake Tahoe. Cattlemans detention basin is the focus of the 7-acre study area and is located in South Lake Tahoe, California (fig. 2).

Hydraulic conductivity of the alluvium in the vicinity of Cattlemans detention basin was estimated using slug tests so that ground-water velocities could be assessed. Groundwater flow direction and velocities around the detention basin affect dissolved nitrate concentrations of runoff filtering through alluvium. Ground-water flow in the study area must be quantified to evaluate how nutrient loads to Cold Creek and Lake Tahoe are affected by Cattlemans detention basin.

\section{Purpose and Scope}

Techniques and methods used to calculate the approximate hydraulic conductivity of the alluvium near Cattlemans detention basin, South Lake Tahoe, California are described in this report. A brief description of Cattlemans detention basin and geology of the area is provided, as well as a detailed discussion of how hydraulic conductivity was approximated for each monitoring well. The distribution of hydraulic conductivity near the detention basin also is reported. 

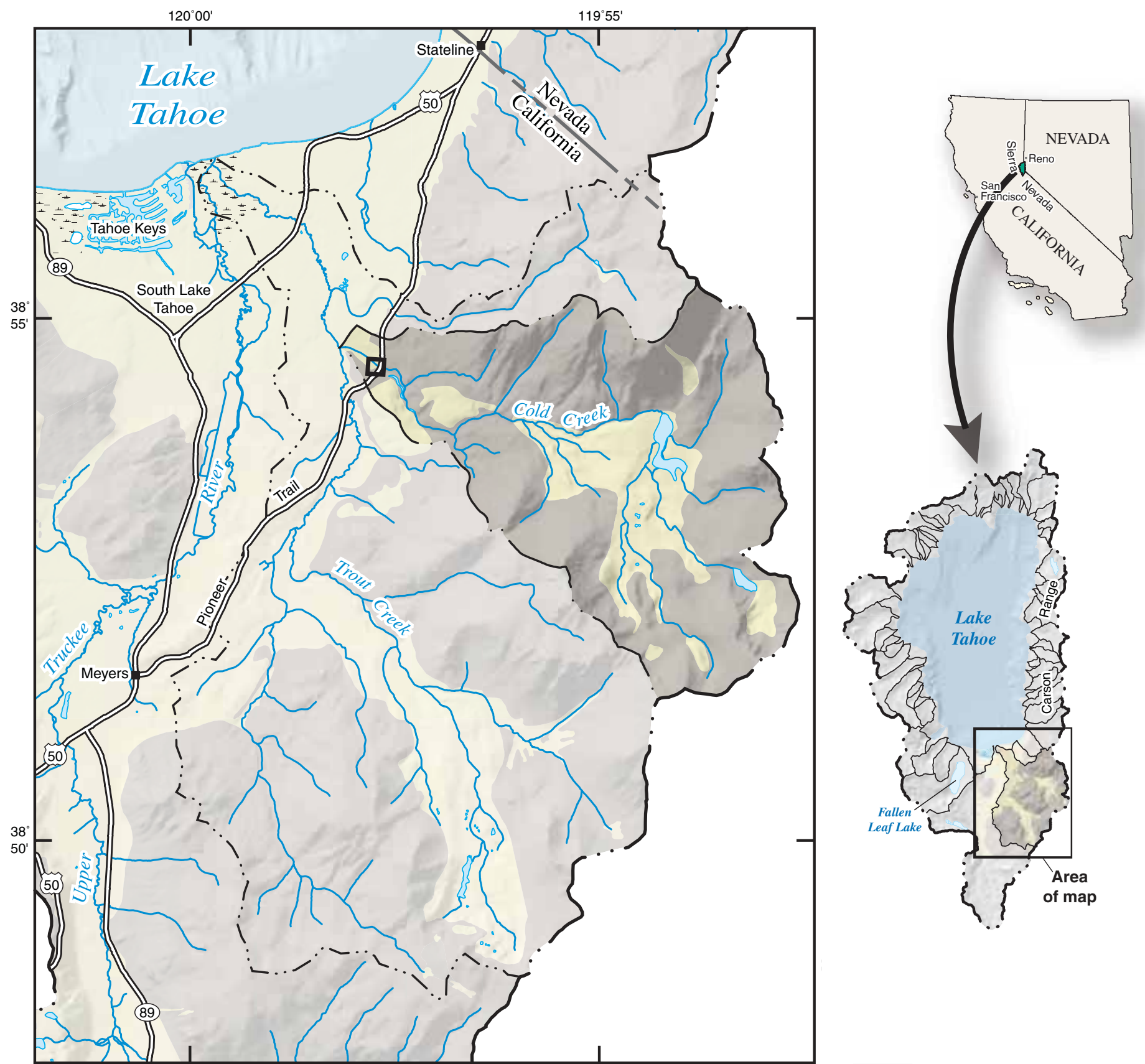

Base from U.S. Geological Survey digital data, 1:24,000 and 1:100,000, 1969-85 Universal Transverse Mercator projection, Zone 10

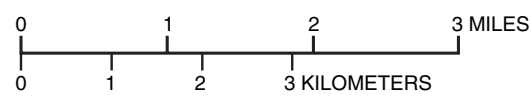

\section{EXPLANATION}

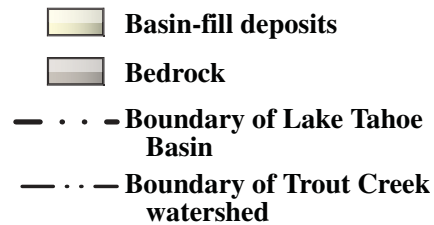

Figure 1. Location of Cattlemans detention basin with respect to Lake Tahoe and California. 


\section{Acknowledgments}

The authors acknowledge employees from the El Dorado County Department of Transportation, Tahoe Engineering Unit who participated in this study. Clayton Chappell and Janell Gifford from the Tahoe Engineering Unit and Kim Carr from the California Tahoe Conservancy were instrumental in developing the work plan and for securing funding for this study. The authors would also like to thank David E. Prudic and James L. Wood for their dedicated assistance during all stages of this study.

\section{Description of Cattlemans Detention Basin}

Cattlemans detention basin is constructed on a meadowlike flat plain that is bordered to the east by Pioneer Trail and to the north and west by Cold Creek (fig. 2). A residential area is located at the south border. Access to the basin is located at the Cattlemans Court cul-de-sac.

Construction of Cattlemans detention basin began in August 2001 and was completed by October 2001. It is designed to hold a total volume of $22,000 \mathrm{ft}^{3}$ of water without surface discharge. Large boulders and concrete were used in constructing a spillway on the west side of the detention basin to allow discharge when the capacity of the basin is exceeded. Flow over the spillway enters the adjacent meadow, which is restrained by bundled straw, or a biolog, to prevent overflow from the basin from directly entering Cold Creek (fig. 2).

A series of 30 shallow monitoring wells were installed at land surface around the detention basin to aid in determining whether nutrients are transported away from the detention basin by ground water (fig. 2). Wells were placed to the east and south of the basin where land-surface elevation was higher, and between Cold Creek and the basin, as well as in the meadow west of the spillway where land-surface elevation was lower. Data collected from the wells were used to estimate the direction and rate of ground-water flow from the detention basin to Cold Creek, and to evaluate changes in chemistry.

\section{Geology of Lake Tahoe and the detention basin}

Lake Tahoe was formed as a result of horst and graben faulting sometime between 7.4 and 2.6 million years ago (Ma) after andesitic volcanism and deformation (Gardner and others, 2000). An irregular oval in shape, Lake Tahoe stretches nearly $22 \mathrm{mi}$ from north to south and $12 \mathrm{mi}$ from west to east (Crippen and Pavelka, 1972). Ranked as the twelfth deepest lake in the world, Lake Tahoe is one of the largest lakes in the United States (Gardner and others, 2000). The lake has an average depth of $1,000 \mathrm{ft}$ (greatest depth is $1,645 \mathrm{ft}$ ) and a total surface area of $191 \mathrm{mi}^{2}$. The Nevada-California state line passes through the lake; about $57 \mathrm{mi}^{2}$ of the lake is in Nevada and $134 \mathrm{mi}^{2}$ is in California (Crippen and Pavelka, 1972).
Granitic rocks (mainly granodiorite) underlie much of the lake and the adjacent uplands. Andesitic volcanic rocks cover much of the northern and northwestern areas of the Lake Tahoe basin, whereas granitic rocks are covered by Quaternary glacial and alluvial deposits on the southwestern and southern end (Gardner and others, 2000).

At the site of Cattlemans detention basin, just above the confluence of Trout and Cold Creeks, alluvium covers the granitic rocks. The alluvial deposits primarily are floodplain sediments composed of silt and sand, and stream channel sediments composed of sand and gravel with locally interbedded lacustrine silt and clay (Harrill, 1977). The alluvium ranges from 10 to 20 -ft thick near the mountains (including the study area) and as much as $500 \mathrm{ft}$ thick near Lake Tahoe. Prior to the detention basin construction, 4 to $5 \mathrm{ft}$ of fill was placed on top of the meadow in the study area during construction of the residential area. However, a large part of the fill was removed during the construction of the detention basin. It is characterized as a red-brown loamy sand with some gravel and scarce cobbles. The fill overlies a layer of dark gray (nearly black) organic-rich soil containing decomposing plant material. Due to the high organic content, this thin layer most likely was once the old meadow surface.

Below the highly organic layer is a medium to dark gray organic silt and sand with stringers of coarse sand and fine gravel. Generally, the thickness of these deposits range from 5 to $8 \mathrm{ft}$. Mica flakes are common in the silt and sand. Roots of the meadow grasses are common to a depth of one foot and sporadic decomposing wood pieces are found throughout the deposit.

The third layer in the detention basin area is a brown to yellow-brown sand and gravel. Although the thickness of this layer is unknown, it is found below the organic sandy silt layer. The yellow-brown color is the result of oxidation of iron. Granitic rock underlies the sand and gravel layer and was found when drilling well cc2 at a depth of about $6 \mathrm{ft}$ below land surface. A cross section of the detention basin is shown in figure 3 .

\section{Estimates of Hydraulic Conductivity}

\section{Well Construction}

A series of monitoring wells were installed in the vicinity of Cattlemans detention basin in November and December 2000. A total of 30 wells were installed prior to the actual construction of the detention basin. The purpose of the wells was to determine the depth of ground water, the direction of flow, the distribution of hydraulic conductivity, and ground-water chemistry prior to and after construction of the detention basin.

Wells located in the area of the fill (well sites cc3-cc6, cc8-cc10, cc13, and cc15; table 1 and fig. 2) were installed in boreholes drilled to depths of 9 to $10 \mathrm{ft}$ using a trailer mounted hollow-stem auger. These wells were completed in the gray silt and sand. Deeper wells (depths of $15 \mathrm{ft}$ ) were installed adjacent 

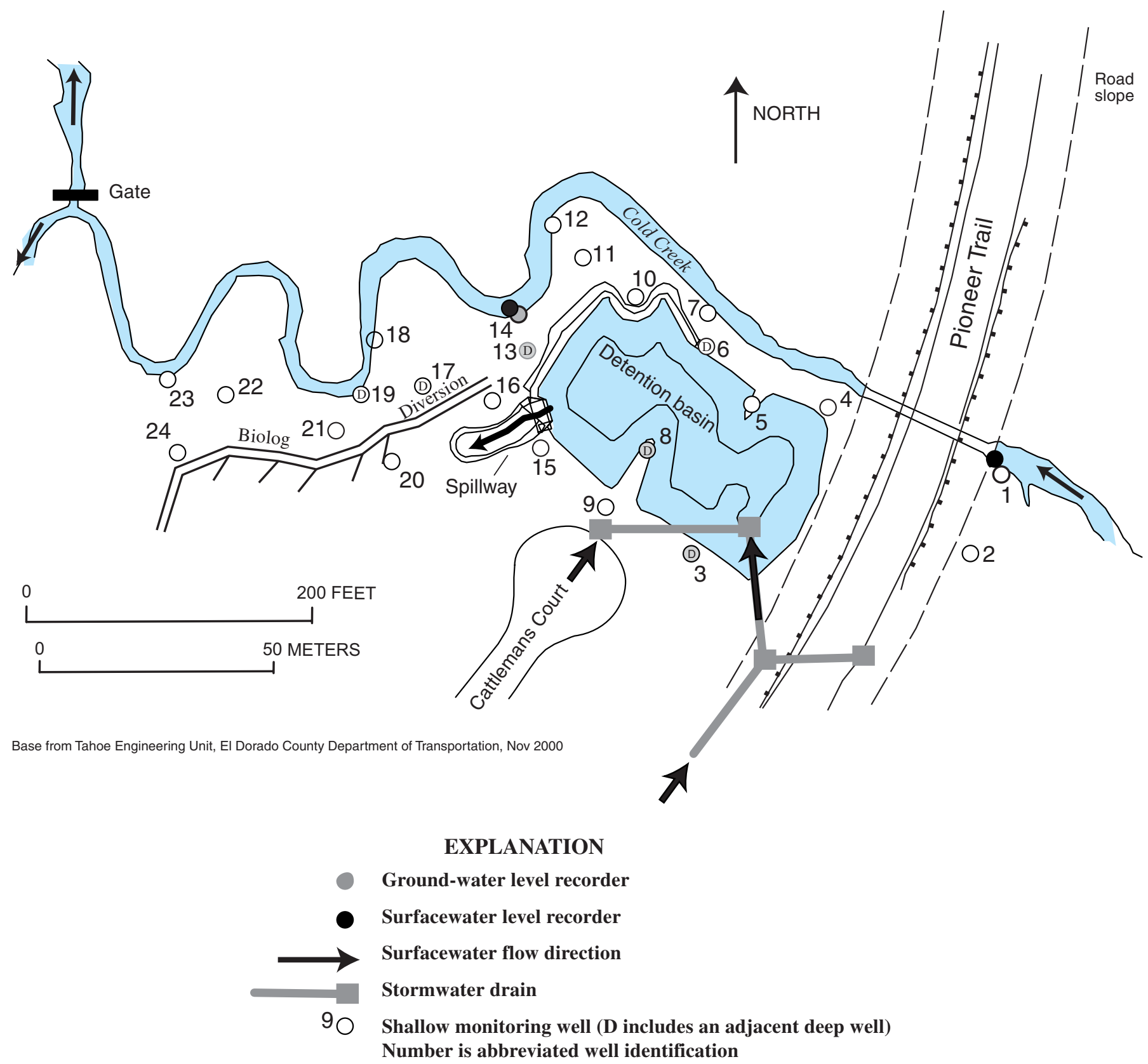

Figure 2. Cattlemans detention basin in relation to Cold Creek, Pioneer Trail, and Cattlemans Court, South Lake Tahoe, California. Well identification numbers are abbreviated by omitting the "cc" designation preceding each number.

to the shallow wells at well sites cc3, cc6, cc8, and cc13 (table 1 and fig. 2). Wells located in areas not covered by fill (in the meadow and next to stream) were installed in boreholes augered by hand (cc1-cc2, cc7, cc11-cc12, cc14, and cc16-cc24; table 1 and fig. 2). Most of the wells were instated in boreholes augered to depths of 5 to $7 \mathrm{ft}$ and a diameter of $4.5 \mathrm{in}$. Depth to ground water during installation ranged from 2 to $5 \mathrm{ft}$. Deeper wells (depths of 10 to $11 \mathrm{ft}$ ) were installed adjacent to the shallow wells at well sites cc17 and cc19. In this report, a shallow well adjacent to the deeper well at a well site is designated by an $\mathrm{S}$ following the well site number (for example; well cc3S, table 1) and the deeper well is designated by a $\mathrm{D}$ following the well site number (for example; well cc3D, table 1). The purpose of the deeper wells was to determine whether ground-water flow or chemistry changed with depth.

All wells, except well cc 2 and cc19D, consisted of nominal 2-in. schedule 40 PVC (polyvinyl chloride) pipe. Openings were cut into the pipe from 0.5 and $1.5 \mathrm{ft}$ from the bottom at a width of $0.020 \mathrm{in}$. to form a screened interval in the well. Stainless steel rivets were used to secure a cap to the bottom of the pipe. A 5-ft section of flush threaded PVC was added to wells that were deeper than $10 \mathrm{ft}$. The joint was sealed with a Teflon 


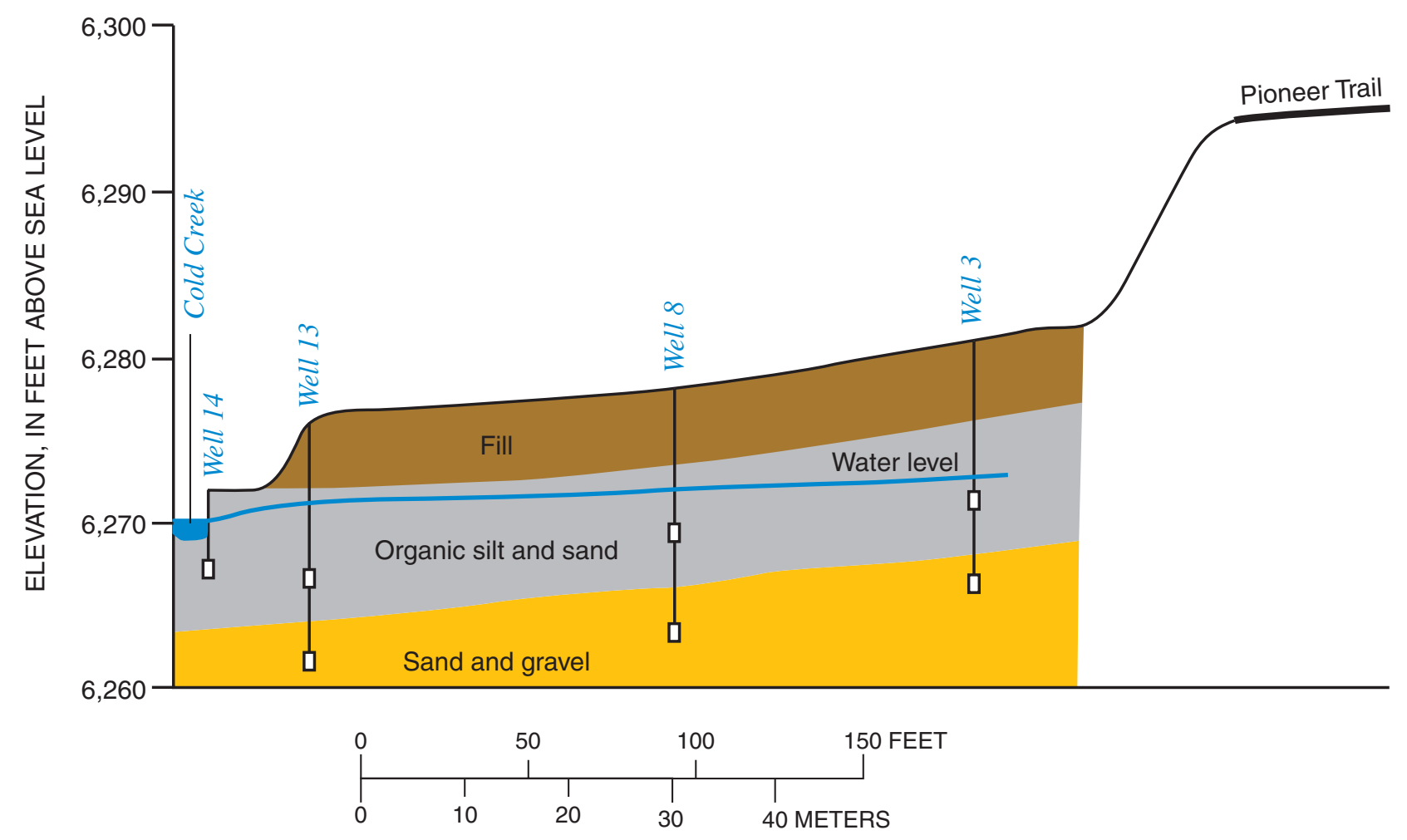

Figure 3. Distribution of alluvial deposits and fill materials between well 3 and well 14 at Cattlemans detention basin, South Lake Tahoe, California. Well identification numbers are abbreviated by omitting the "cc" designation preceding each number.

O-ring. Any excess casing that extended above land surface was cut off. Two wells, cc2 and cc19D, consisted of nominal 1-in. schedule 40 PVC pipe. This pipe had the same openings as the nominal 2-in. PVC pipe and was used in places where a smaller diameter auger bucket was needed to reach the desired depth.

All 2-in. monitoring wells were topped with a tightly sealed cap composed of two O-rings in order to prevent inflow of surface runoff into the well. Each cap is lockable. The two 1-in. diameter wells also were capped, but a rubber gasket was used to seal the top of the casing instead. Table 1 summarizes the construction information of all 30 monitoring wells installed in the area of the detention basin.

The annular space around each well casing was backfilled using a variety of material (fig. 4) beginning with very coarse silica sand (0.04 to 0.08 in.) that was placed around and slightly above the screen $(0.5$ to $1 \mathrm{ft})$. Silica flour, 1 to $3-\mathrm{ft}$ thick, was placed on top of the silica sand and was designed to restrict vertical flow in the borehole. Although a bentonite grout typically is used to restrict vertical flow, silica flour was used instead to eliminate possible reactions of the sodium-rich bentonite with the ground water. The native material that initially was removed from the borehole was added until it reached approximately $2 \mathrm{ft}$ from the land surface. Neat cement was poured in the top $2 \mathrm{ft}$ and around the well cap to form a surface-seal for the borehole.

\section{Method}

Slug tests were done in a similar manner on 27 of the 30 monitoring wells. Usually, slug tests were repeated more than once on each well. Three wells (cc17S, cc17D, and cc2) were not tested. Prior to the start of a slug test, the depth to water was measured and recorded using either a steel or electric tape. In several wells, about $1 \mathrm{gal}$ of water was pumped from the well, and the water level was allowed to recover to its static level. Once the water level recovered to its static level, a recording pressure transducer (Global Water Instrumentation Inc. WL15003) that has a range from 0 to $3 \mathrm{ft}$ was lowered and secured $1 \mathrm{ft}$ below the water level. Continuous pressure readings were made until they had stabilized. After the pressure readings stabilized, the transducer was set to record every 1 to 2 seconds.

Each test consisted of rapidly pouring 0.079 to 0.26 gal of water from a graduated cylinder into the well (usually within 1 to 2 seconds) to imitate an instantaneous slug of water. This volume was sufficient to raise the water level in the well 1 to $2 \mathrm{ft}$. The time of each test was recorded. For most wells, either deionized water or water that had been previously pumped from the well was used for the tests. Water from Cold Creek was used in wells adjacent to Cold Creek. Water levels were measured using either a steel or electric tape after approximately one minute. If the water had not returned to its static level, a measurement was taken every 1 to 2 minutes thereafter until it had 
Table 1. Well name, land-surface elevation, and construction data for 30 monitoring wells in vicinity of Cattlemans detention basin, South Lake Tahoe, California

\begin{tabular}{|c|c|c|c|c|c|}
\hline \multirow{3}{*}{$\begin{array}{c}\text { Well } \\
\text { name }\end{array}$} & \multirow{3}{*}{$\begin{array}{c}\text { Standard } \\
\text { identification } \\
\text { number }\end{array}$} & \multirow{3}{*}{$\begin{array}{l}\text { Land- surface } \\
\text { elevation }{ }^{1} \\
\text { (feet) }\end{array}$} & \multicolumn{3}{|c|}{$\begin{array}{c}\text { Depth } \\
\text { (feet below land surface) }\end{array}$} \\
\hline & & & \multirow{2}{*}{$\begin{array}{l}\text { Bottom of } \\
\text { well }\end{array}$} & \multicolumn{2}{|c|}{ Screened interval } \\
\hline & & & & Top & Bottom \\
\hline $\mathrm{cc1}$ & 385432119574001 & 6278.84 & 5.6 & 4.1 & 5.1 \\
\hline $\operatorname{cc} 2$ & 385432119574002 & 6281.57 & 6.8 & 5.3 & 6.3 \\
\hline $\operatorname{cc} 3 S$ & 385432119574301 & 6281.23 & 10.2 & 8.7 & 9.7 \\
\hline $\mathrm{cc} 3 \mathrm{D}$ & 385432119574302 & 6281.21 & 15.1 & 13.6 & 14.6 \\
\hline $\operatorname{cc} 4$ & 385433119574201 & 6279.12 & 10.2 & 8.7 & 9.7 \\
\hline $\operatorname{cc5}$ & 385433119574202 & 6278.03 & 10.2 & 8.7 & 9.7 \\
\hline $\operatorname{cc} 6 \mathrm{~S}$ & 385433119574301 & 6277.37 & 9.0 & 7.5 & 8.5 \\
\hline cc6D & 385433119574302 & 6277.40 & 15.0 & 13.5 & 14.5 \\
\hline $\operatorname{cc} 7$ & 385433119574203 & 6273.29 & 5.0 & 3.5 & 4.5 \\
\hline $\operatorname{cc} 8 \mathrm{~S}$ & 385432119574303 & 6278.13 & 9.2 & 7.7 & 8.7 \\
\hline $\mathrm{cc} 8 \mathrm{D}$ & 385432119574304 & 6278.15 & 15.0 & 13.5 & 14.5 \\
\hline $\operatorname{cc} 9$ & 385432119574305 & 6279.30 & 9.9 & 8.4 & 9.4 \\
\hline $\operatorname{cc} 10$ & 385433119574303 & 6276.39 & 10.2 & 8.7 & 9.7 \\
\hline $\operatorname{cc} 11$ & 385434119574401 & 6272.83 & 5.6 & 4.1 & 4.6 \\
\hline $\operatorname{cc} 12$ & 385434119574402 & 6272.64 & 5.1 & 3.6 & 4.6 \\
\hline $\operatorname{cc} 13 S$ & 385433119574401 & 6275.14 & 10.2 & 8.7 & 9.7 \\
\hline $\mathrm{cc} 13 \mathrm{D}$ & 385433119574402 & 6275.69 & 15.2 & 13.7 & 14.7 \\
\hline $\operatorname{cc} 14$ & 385433119574403 & 6272.60 & 5.5 & 4.0 & 5.0 \\
\hline $\operatorname{cc} 15$ & 385432119574401 & 6278.33 & 10.2 & 8.7 & 9.7 \\
\hline $\operatorname{cc} 16$ & 385433119574404 & 6273.47 & 7.2 & 5.7 & 6.7 \\
\hline $\mathrm{cc} 17 \mathrm{~S}$ & 385433119574501 & 6272.71 & 6.7 & 5.2 & 6.2 \\
\hline cc17D & 385433119574502 & 6272.82 & 10.6 & 9.1 & 10.1 \\
\hline $\operatorname{cc} 18$ & 385433119574503 & 6271.93 & 5.1 & 3.6 & 4.6 \\
\hline cc19S & 385433119574504 & 6272.19 & 5.6 & 4.1 & 5.1 \\
\hline cc19D & 385433119574505 & 6272.11 & 10.0 & 8.5 & 9.5 \\
\hline $\operatorname{cc} 20$ & 385432119574501 & 6272.77 & 7.2 & 5.7 & 6.7 \\
\hline $\operatorname{cc} 21$ & 385432119574601 & 6272.19 & 5.0 & 3.5 & 4.5 \\
\hline $\operatorname{cc} 22$ & 385433119574701 & 6271.94 & 5.6 & 4.1 & 5.1 \\
\hline $\operatorname{cc} 23$ & 385433119574702 & 6271.08 & 5.4 & 3.9 & 4.9 \\
\hline $\operatorname{cc} 24$ & 385432119574701 & 6271.97 & 5.5 & 4.0 & 5.0 \\
\hline
\end{tabular}




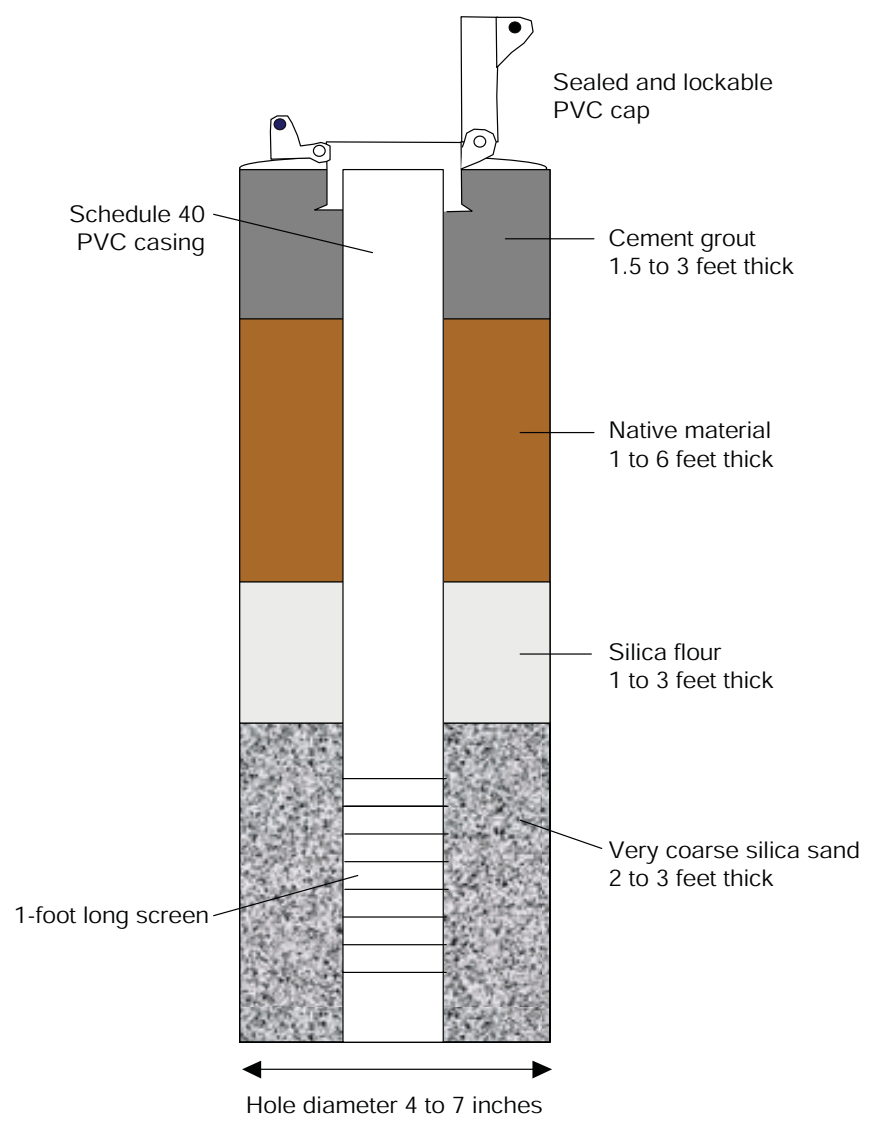

Figure 4. Construction of wells near Cattlemans detention basin, South Lake Tahoe, California.

returned to within $0.02 \mathrm{ft}$. The time of the water level's recovery was documented. This process was repeated until the determined number of slug tests was completed on each well.

Data from the pressure transducers were downloaded from a Personal Digital Assistant (PDA; Palm Inc., Model m105 Handheld) to an on-site laptop computer using Windows XP and plotted on an $x-y$ graph to view the quality of the pressure data. This was done to insure that the pressure transducer was recording pressure every 1 to 2 seconds and that the pressure transducer had not accidentally slipped from its secured position. In some instances, supplemental tests were done because the pressure transducer had not been correctly set or because it had inadvertently slipped.

\section{Results}

Slug tests were analyzed with Bouwer and Rice (1976) in a spreadsheet (Halford and Kuniansky, 2002). Pressure data from each slug test was imported directly into the spreadsheet. Other required information for analysis of each slug test includes well construction information (listed in table 1), the static water level, and the volume of water poured into the well. Estimates of the hydraulic conductivity from slug tests of the 27 wells are summarized in table 2 and shown in the appendix. The appendix summarizes information regarding well construction, static water level, the slug displacement, and estimated hydraulic conductivity, and includes the comparison of the fitted line to measurements recorded by the pressure transducer.

Estimates of hydraulic conductivity are reported only to the nearest significant figure $(0.1,1$, and 10$)$ because errors in the estimates of hydraulic conductivity were found to range from 10 to 25 percent (Bouwer and Rice, 1976). However, a more recent analysis indicates errors ranging from 10 to 100 percent (Brown and others, 1995). Furthermore, the Bouwer and Rice method tends to underestimate the hydraulic conductivity (Brown and others, 1995). Pouring water as quickly as possible down the well is not instantaneous as the method assumes. A percentage of the volume of water leaked through the screen and into the alluvium as it was poured into the well. Thus, for slug tests having estimated hydraulic conductivities exceeding a few feet per day, the effective volume of water used in the computation of $y_{0}$ was always less than the actual volume poured into the well. The discrepancy between the effective volume and the actual volume was greater with increased hydraulic conductivity. The largest discrepancies were recorded in wells that had estimated hydraulic conductivities that exceeded $10 \mathrm{ft} / \mathrm{d}$. The time it took to pour water into the well generally was less than 4 seconds. For the well with the highest estimated hydraulic conductivity (well cc6S), the estimated rise in water level at time zero should have been $1.45 \mathrm{ft}$ assuming that $0.238 \mathrm{gal}$ of water was poured instantly into the well. The estimated hydraulic conductivity was no different when the rise of $1.45 \mathrm{ft}$ was assumed at time zero and the next water level measurement was made at 4 seconds. Assuming the time of the next measurement was 3 seconds instead of 4 seconds, the hydraulic conductivity would increase by $10 \mathrm{ft} / \mathrm{d}$ and the error would be 15 percent.

The slug test results from well cc2 are not included in the overall analysis of Cattlemans detention basin. This is because well cc2 is located at a higher elevation than the other wells and the static water level was within the screened interval of the well. When water was poured into the well, it also had to fill the gravel pack surrounding the well above the initial water level. There is no correction within the Bouwer and Rice analysis that corrects for this situation and therefore these tests were not included in the analysis. 
Table 2. Results of slug tests in wells near Cattlemans detention basin, South Lake Tahoe, California

\begin{tabular}{|c|c|c|c|c|c|}
\hline $\begin{array}{c}\text { Well } \\
\text { name }\end{array}$ & $\begin{array}{l}\text { Date } \\
\text { of } \\
\text { test }\end{array}$ & $\begin{array}{c}\text { Initial } \\
\text { water level } \\
\text { elevation } 1 \\
\text { (feet) }\end{array}$ & $\begin{array}{c}\text { Average } \\
\text { displacement } \\
\text { (feet) }\end{array}$ & $\begin{array}{c}\text { Estimated } \\
\text { hydraulic } \\
\text { conductivity } \\
\text { (feet per day) }\end{array}$ & $\begin{array}{c}\text { Number } \\
\text { of } \\
\text { slug tests }\end{array}$ \\
\hline cc1 & $11 / 06 / 03$ & 6275.85 & 1.57 & 1 & 2 \\
\hline $\operatorname{cc} 3 S$ & $11 / 06 / 03$ & 6272.43 & 1.45 & 2 & 3 \\
\hline $\operatorname{cc} 3 \mathrm{D}$ & $11 / 06 / 03$ & 6272.45 & 1.22 & 10 & 3 \\
\hline $\operatorname{cc} 4$ & $11 / 06 / 03$ & 6273.47 & 1.21 & 10 & 3 \\
\hline $\operatorname{cc} 5$ & $11 / 06 / 03$ & 6272.33 & 1.19 & 20 & 3 \\
\hline $\operatorname{cc} 6 \mathrm{~S}$ & $11 / 06 / 03$ & 6271.5 & 1.02 & 70 & 4 \\
\hline cc6D & $11 / 06 / 03$ & 6271.53 & 1.05 & 30 & 3 \\
\hline $\mathrm{cc} 7$ & $11 / 06 / 03$ & 6271.68 & 1.13 & 10 & 3 \\
\hline $\operatorname{cc} 8 \mathrm{~S}$ & $05 / 27 / 03$ & 6274.44 & 1.28 & 10 & 2 \\
\hline $\mathrm{cc} 8 \mathrm{D}$ & $05 / 27 / 03$ & 6274.32 & 1.02 & 20 & 3 \\
\hline \multirow[t]{2}{*}{$\operatorname{cc} 9$} & 06/10/03 & 6272.95 & 0.89 & 40 & 3 \\
\hline & $10 / 30 / 03$ & 6271.68 & & & \\
\hline cc10 & $06 / 09 / 03$ & 6272.05 & 0.95 & 30 & 3 \\
\hline cc11 & $10 / 30 / 03$ & 6270.46 & 1.08 & 2 & 6 \\
\hline cc12 & 06/10/03 & 6271.72 & 0.96 & 20 & 3 \\
\hline $\mathrm{cc} 13 \mathrm{~S}$ & $05 / 27 / 03$ & 6272.34 & 0.93 & 20 & 5 \\
\hline cc13D & $05 / 27 / 03$ & 6271.81 & 1.11 & 10 & 3 \\
\hline cc14 & $05 / 27 / 03$ & 6270.91 & 0.88 & 20 & 3 \\
\hline cc15 & $10 / 30 / 03$ & 6271.12 & 1.04 & 10 & 5 \\
\hline cc16 & $06 / 10 / 03$ & 6271.82 & 1.08 & 5 & 3 \\
\hline cc18 & $11 / 06 / 03$ & 6269.52 & 1.29 & 40 & 3 \\
\hline \multirow[t]{2}{*}{ cc19S } & $11 / 06 / 03$ & 6269.54 & 1.2 & 1 & 1 \\
\hline & $06 / 24 / 03$ & 6270.26 & & & 1 \\
\hline cc19D & $06 / 24 / 03$ & 6270.19 & 1.64 & 0.5 & 2 \\
\hline $\operatorname{cc} 20$ & $06 / 10 / 03$ & 6271.11 & 0.93 & 20 & 1 \\
\hline $\operatorname{cc} 21$ & $06 / 10 / 03$ & 6270.53 & 0.93 & 10 & 1 \\
\hline $\operatorname{cc} 22$ & $06 / 10 / 03$ & 6269.99 & 1.13 & 40 & 4 \\
\hline $\operatorname{cc} 23$ & $11 / 06 / 03$ & 6268.69 & 1.41 & 20 & 3 \\
\hline $\operatorname{cc} 24$ & $06 / 10 / 03$ & 6269.58 & 0.93 & 10 & 1 \\
\hline
\end{tabular}

${ }^{1}$ Land-surface elevation referenced to pin set by El Dorado County Department of Transportation at end of Cattlemans Court cul-de-sac. Elevation referenced to NAVD of 1988.

2 Wells tested only once include exact displacement. 


\section{Discussion}

The estimated hydraulic conductivities of the alluvium near Cattlemans detention basin range from 0.5 to $70 \mathrm{ft} / \mathrm{d}$ (fig. 5). The distribution is slightly skewed with the majority of estimated hydraulic conductivities ranging from 1 to $20 \mathrm{ft} / \mathrm{d}$ (fig. 6). There were six estimates that exceeded $20 \mathrm{ft} / \mathrm{d}$ and only one estimate that was less than $1 \mathrm{ft} / \mathrm{d}$. The mean (average) value of hydraulic conductivity is $17.8 \mathrm{ft} / \mathrm{d}$, whereas the median value is $10 \mathrm{ft} / \mathrm{d}$. The 25 th percentile is at $10 \mathrm{ft} / \mathrm{d}$ and the $75 \mathrm{th}$ percentile is at $20 \mathrm{ft} / \mathrm{d}$ indicating that at least half of all estimates range from 10 to $20 \mathrm{ft} / \mathrm{d}$. The estimates of hydraulic conductivity from these slug tests are consistent for alluvial deposits that are a silty to clean sand (Freeze and Cherry, 1979) and are thus consistent with the texture of the alluvial deposits that were found when the monitoring wells were augered.

No significant conclusions can be drawn between estimated hydraulic conductivities between the shallow and deeper wells due to a lack of sufficient estimates in the deeper wells. With only five estimates of hydraulic conductivity of the deeper sand and gravel, there is not enough evidence to support differences in the hydraulic conductivities between the shallow meadow deposits and the deeper sand and gravel.

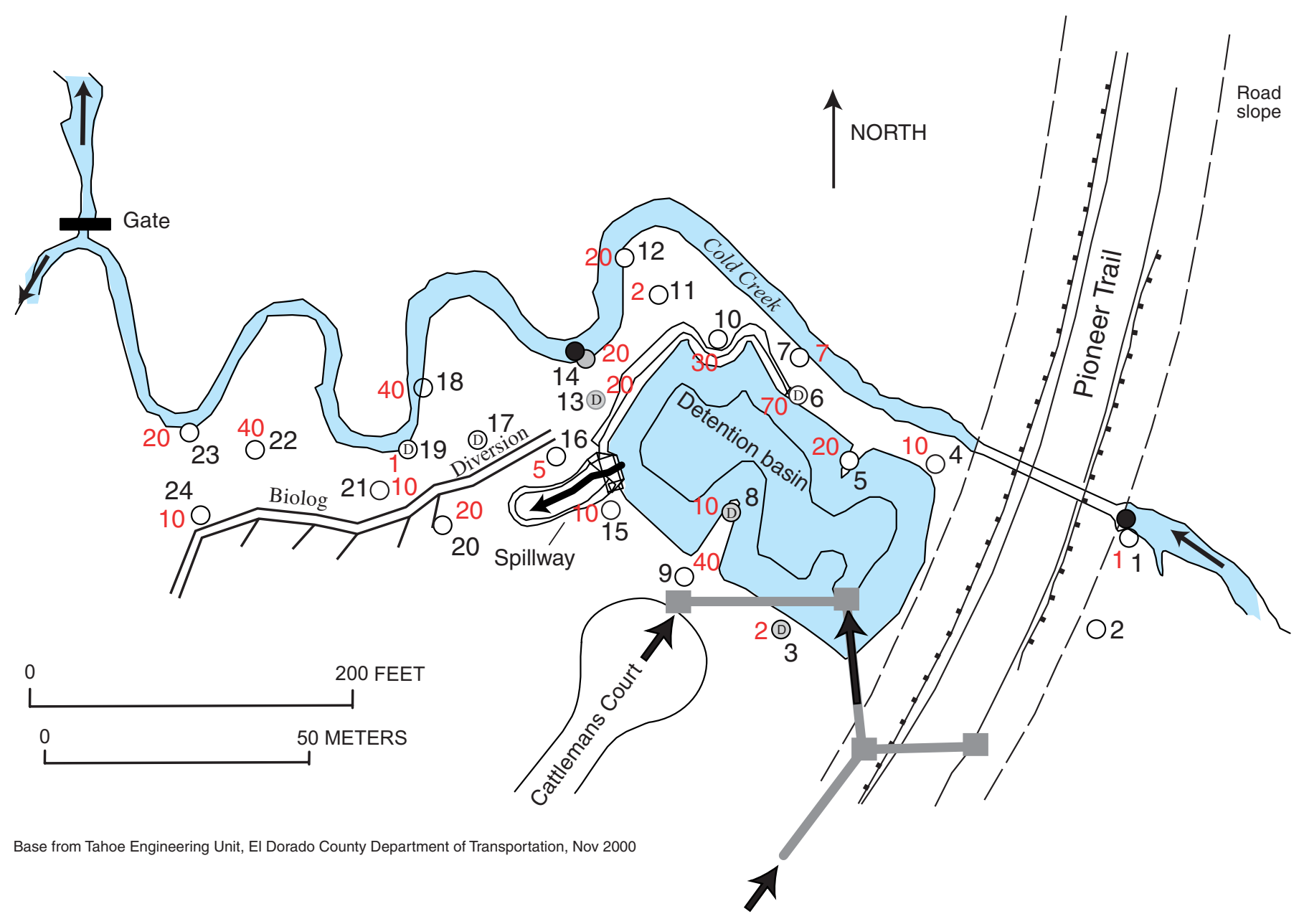

EXPLANATION

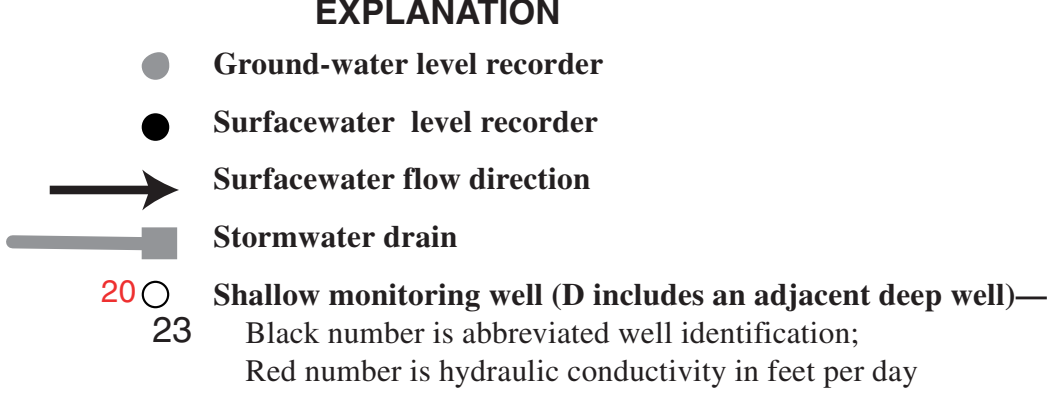

Figure 5. Distribution of hydraulic conductivity near Cattlemans detention basin, South Lake Tahoe, California. Well identification numbers are abbreviated by omitting the "cc" designation preceding each number. 


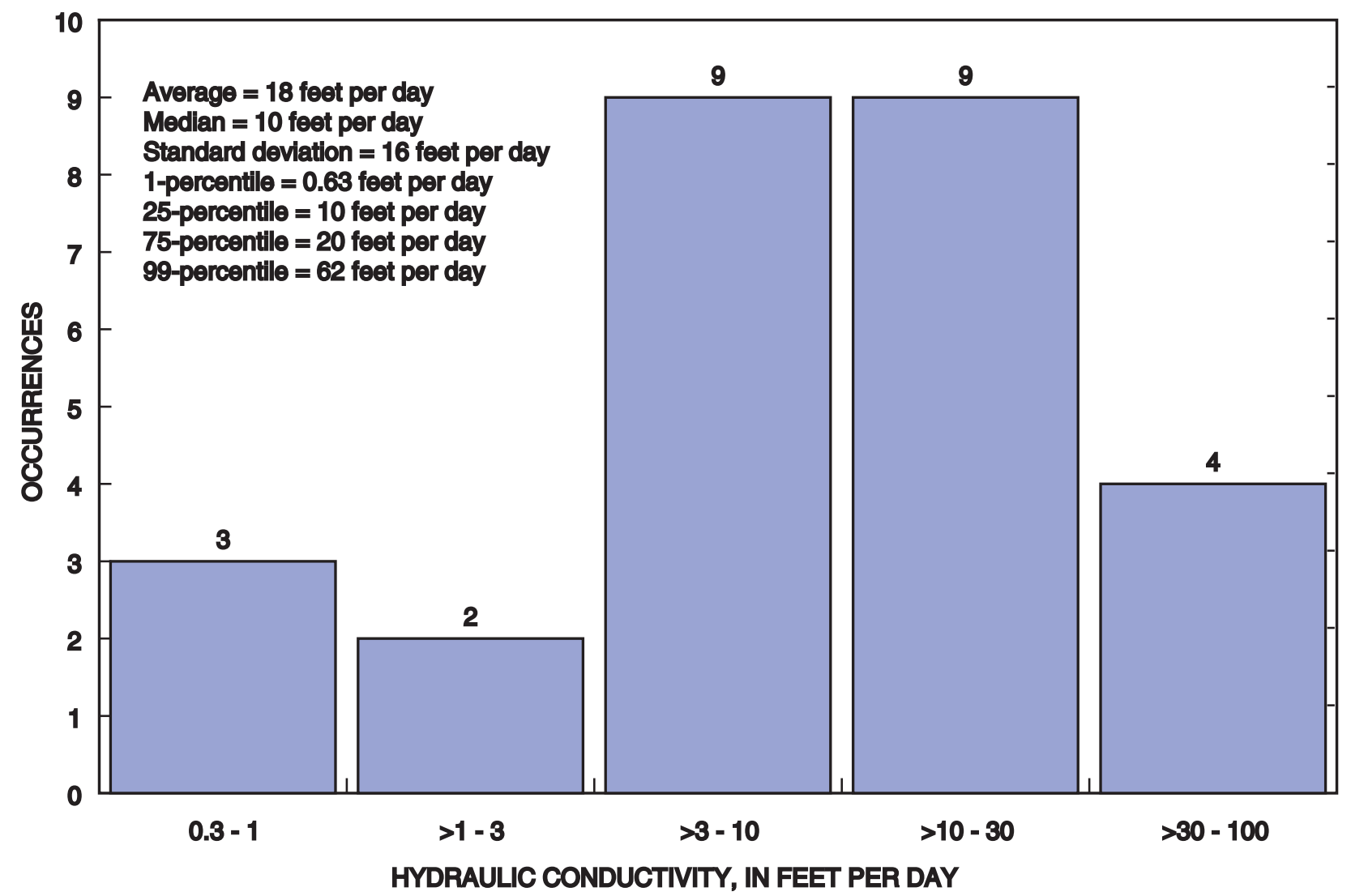

Figure 6. Range of hydraulic conductivity in all tested wells near Cattlemans detention basin, South Lake Tahoe, California.

\section{Summary and Conclusions}

Cattlemans detention basin project is a five-year study that began in November 2000 in cooperation with the El Dorado County Department of Transportation, Tahoe Engineering Unit and the California Tahoe Conservancy. The purpose of this study is to determine if the installation of Cattlemans detention basin reduces nutrients and sediments in surface flow before entering Lake Tahoe. Estimating hydraulic conductivity of the alluvium near Cattlemans detention basin is important in evaluating the subsurface transport of nutrients from the detention basin to nearby Cold Creek. The purpose of this report is to describe the techniques and methods used to estimate the hydraulic conductivity of the alluvium and to present the results of the analysis.

A total of 30 shallow monitoring wells were installed in the vicinity of the detention basin, ranging in depth from 5 to $15 \mathrm{ft}$, to assess the direction and rate of ground-water flow. Hydraulic conductivity was estimated by testing 27 wells ( 22 in the shallow meadow deposits and 5 in the deeper sand and gravel). Estimates of hydraulic conductivity were determined using the Bouwer and Rice analysis of slug tests. The response of the slug test was recorded every 1 to 2 seconds using a recording pressure transducer, which had a range from 0 to $3 \mathrm{ft}$, after 0.079 to $0.26 \mathrm{gal}$ of water was rapidly poured down each well.

Hydraulic conductivities of the alluvium ranged from 0.5 to $70 \mathrm{ft} / \mathrm{d}$, with more than half between 10 and $20 \mathrm{ft} / \mathrm{d}$. The range in hydraulic conductivity is consistent with the sandy texture of the alluvial deposits. Estimates of hydraulic conductivity were reported only to the nearest significant figure because a percentage of the water poured into the well leaked through the screen and into the alluvium as it was poured into the well. This caused a discrepancy between measured water-level displacement and that which was estimated from the volume of water poured into the well. For the well with the highest estimated hydraulic conductivity (well cc6S), the estimated rise in water level at time zero should have been $1.45 \mathrm{ft}$ assuming that 0.238 gal of water was poured instantly into the well. The estimated hydraulic conductivity was no different when the rise of $1.45 \mathrm{ft}$ was assumed at time zero and the next water level measurement was in 4 seconds. Assuming the time of the next measurement was 3 seconds instead of 4 seconds, the hydraulic conductivity increased by $10 \mathrm{ft} / \mathrm{d}$ and the error would be 15 percent. 


\section{References Cited}

Bouwer, Herman, and Rice, R.C., 1976, A slug test for determining hydraulic conductivity of unconfined aquifers with completely or partially penetrating wells: Water Resources Research, v. 12, no. 3, p. 423-428.

Brown, D.L., Narasimhan, T.N., and Demir, Z., 1995, An evaluation of the Bouwer and Rice method of slug test analysis: Water Resources Research, v. 31, no. 5, p. 1239-1246.

Crippen, J.R. and Pavelka, B.R., 1970, The Lake Tahoe Basin, California-Nevada: U.S. Geological Survey Water-Supply Paper 1972, $56 \mathrm{p}$.

Freeze, R.A., and Cherry, J.A., 1979, Groundwater: Englewood Cliffs, N.J., Prentice-Hall, 604 p.
Gardner, J.V., Mayer, L.A., and Hughs Clarke, J.E., 2000, Morphology and process in Lake Tahoe, California-Nevada: Geological Society of America Bulletin, v. 112, no. 5, p. 736-746.

Halford, K.J., and Kuniansky, E.L., 2002, Spreadsheets for the analysis of aquifer-test and slug-test data, version 1.1: U.S. Geological Survey Open-File Report 02-197, 51 p. (available on the World Wide Web at http://water.usgs.gov/pubs/ of/ofr02197).

Harrill, J.R., 1977, Hydrologic Map, South Lake Tahoe Folio: Reno, Nevada, Nevada Bureau of Mines and Geology Environmental Series, Lake Tahoe Area, map no. 2Af, 1 sheet. 
